\title{
Odpowiedzialność za produkt żywnościowy w polskim systemie prawnym
}

\section{Zagadnienia wprowadzające}

Sprecyzowanie zasad i podstaw odpowiedzialności za produkt żywnościowy wchodzi w zakres niezwykle obszernej problematyki bezpieczeństwa żywności. Ramy artykułu nie pozwalają na analizę jurydyczną całości zagadnień związanych $\mathrm{z}$ bezpieczeństwem żywności w polskim systemie prawnym.

Nie tracąc z pola widzenia całego oprzyrządowania prawnego w zakresie bezpieczeństwa, dostępnego w polskim systemie prawnym żywności, uwaga zostanie skoncentrowana na cywilnoprawnych aspektach odpowiedzialności producenta za szkodę spowodowaną wadą produktu żywnościowego. Założeniem artykułu nie jest jednak wyłącznie szczegółowa, jurydyczna analiza polskich rozwiązań prawnych w tej materii, ale przede wszystkim prezentacja i próba wykładni tych przepisów, które rodzą w praktyce polskiej najwięcej wątpliwości, w szczególności z punktu widzenia ich spójności z rozwiązaniami unijnymi. Nie ulega wątpliwości, że harmonizacja prawa w tym obszarze jest niezwykle istotna.

Uwzględniając konieczne wymogi poznawcze niniejszego artykułu, przed podjęciem analizy prawnej problematyki odpowiedzialności o charakterze cywilnoprawnym za produkt żywnościowy, wymaga zasygnalizowania, że w polskim ustawodawstwie zdecydowana większość niezwykle istotnych zagadnień prawnych, dotyczących bezpieczeństwa żywności w ujęciu prawa wspólnotowego (unijnego), znalazła swoje odzwierciedlenie. Obecnie problematykę tę reguluje na polskim obszarze prawnym ustawa z dnia 25 sierpnia 2006 r. o bezpieczeństwie żywności i żywienia ${ }^{1}$. Jej zakres przedmiotowy wyznaczony został $\mathrm{w}$ art. 1 .

Według art. 1 ust. 1 ustawa określa wymagania i procedury niezbędne dla zapewnienia bezpieczeństwa żywności i żywienia zgodnie z przepisami rozporządzenia (WE) nr 178/2002 Parlamentu Europejskiego i Rady z dnia 28 stycznia 2002 r. 
ustanawiającego ogólne zasady i wymagania prawa żywnościowego, powołującego Europejski Urząd do Spraw Bezpieczeństwa Żywności oraz ustanawiającego procedury w sprawie bezpieczeństwa żywności².

Z kolei zgodnie z art. 1 ust. 2 ustawa obejmuje swoim zakresem nie tylko wymagania zdrowotne żywności, ale także wymagania dotyczące przestrzegania zasad higieny żywności w zakresie nieuregulowanym w rozporządzeniu (WE) nr 852/2004 Parlamentu Europejskiego i Rady z dnia 29 kwietnia 2004 r. w sprawie higieny środków spożywczych ${ }^{3}$. Reguluje również kwestie dotyczące przestrzegania zasad higieny materiałów i wyrobów przeznaczonych do kontaktów z żywnością w zakresie nieuregulowanym rozporządzeniem (WE) nr 1935/2004 Parlamentu Europejskiego i Rady z dnia 27 października 2004 r. w sprawie materiałów i wyrobów przeznaczonych do kontaktu z żywnością ${ }^{4}$. Polska ustawa o bezpieczeństwie żywności określa również właściwość organów w zakresie przeprowadzania urzędowych kontroli ${ }^{5}$. Precyzuje także wymagania dotyczące przeprowadzania urzędowych kontroli żywności. ${ }^{6}$

Wymaga podkreślenia, że polska ustawa o bezpieczeństwie żywności - zgodnie z ogólnymi wymogami prawa unijnego - realizuje w zakresie swojej regulacji wymogi pozostałych rozporządzeń Rady oraz Parlamentu Europejskiego i Rady odnoszących się do analizowanej materii, a wymienionych w załączniku do ustawy. Ustawa dokonuje również w zakresie swojej regulacji transpozycji dyrektyw Wspólnot Europejskich, wymienionych w załączniku.

Należy zauważyć, że zagadnienie odpowiedzialności za produkt żywnościowy wchodzi w zakres szerszej problematyki odpowiedzialności za produkt. Szczegółowe zagadnienia obejmujące tę materię znajdują się zarówno w przepisach prawa administracyjnego ${ }^{7}$, ale przede wszystkim w przepisach prawa cywilnego. $\mathrm{W}$ istocie bowiem, kiedy analizie poddajemy reżim prawny odnoszący się do odpowiedzialności za produkt, nasza uwaga koncentruje się na odpowiedzialności o charakterze cywilnoprawnym za szkody spowodowane przez wady produktu. Niektórzy autorzy

2 Dz.Urz. WE L 31 z 01.02.2002, s. 1; Dz.Urz. UE Polskie wydanie specjalne, rozdz. 15, t. 6, s. 463, zwanego dalej "rozporządzeniem nr 178/2002".

3 Dz.Urz. UE L 139 z 30.04.2004, s. 1; Dz.Urz. UE Polskie wydanie specjalne, rozdz. 13, t. 34, s. 319, zwanym dalej "rozporządzeniem nr 852/2004."

4 Dz.Urz. UE L 338 z 13.11.2004, s. 4, rozporządzenie to uchyliło dyrektywy 80/590/EWG i 89/109/EWG.

5 W tej materii ustawa dostosowana jest do wymogów rozporządzenia (WE) nr 882/2004 Parlamentu Europejskiego i Rady z dnia 29 kwietnia 2004 r. w sprawie kontroli urzędowych przeprowadzanych w celu sprawdzenia zgodności z prawem paszowym i żywnościowym oraz regułami dotyczącymi zdrowia zwierząt i dobrostanu zwierząt (Dz.Urz. UE L 191 z 30.04.2004, s. 1; Dz.Urz. UE Polskie wydanie specjalne, rozdz. 3, t. 45, s. 200).

$6 \quad$ Wymagania te są określone w zakresie nieuregulowanym w rozporządzeniu $\mathrm{nr}$ 882/2004.

7 W szczególności w przepisach cytowanej ustawy o bezpieczeństwie żywności, także w części określającej sankcje o charakterze administracyjnym, a nawet prawnokarnym. 
w polskiej doktrynie prawniczej jeszcze bardziej zawężają zakres wady - do wady czyniącej produkt niebezpiecznym dla otoczenia ${ }^{8}$.

Konieczne jest podkreślenie, że omawiana materia znajduje swoje odzwierciedlenie nie tylko w samym polskim kodeksie cywilnym ${ }^{9}$, ale także w szeroko rozumianym prawie konsumenckim. W polskim systemie prawnym wada produktu ujmowana jest bowiem w znacznej mierze właśnie z konsumenckiego punktu widzenia. Niektórzy przedstawiciele doktryny prawniczej ujmują wadę („,wadliwość) produktu bardzo szeroko - jako niezapewnienie bezpieczeństwa produktu w stopniu, w jakim konsument jest uprawniony tegoż bezpieczeństwa oczekiwać ${ }^{10}$. Niepodobna również abstrahować od kwestii, iż tak określony reżim odpowiedzialności może - przynajmniej w niektórych stanach faktycznych - wiązać się z odpowiedzialnością za tzw. szkodę w środowisku i wtedy podstaw odpowiedzialności w polskim systemie prawnym można również poszukiwać w przepisach ustawy z dnia 27 kwietnia 2001 r. - Prawo ochrony środowiska ${ }^{11}$.

\section{Wybrane zagadnienia szczegółowe}

1. Cywilnoprawne aspekty odpowiedzialności za produkt żywnościowy w polskim systemie wymagają analizy prawnej istotnych elementów wyznaczających podstawy i zakres tej odpowiedzialności. Uwzględniając ramy niniejszego opracowania, wyczerpanie całości tej problematyki nie jest możliwe. Uwaga zatem zostanie skoncentrowana na problemach podstawowych.

2. Dla jasności dalszych wywodów, analiza rozwiązań prawnych w sferze cywilnoprawnych aspektów odpowiedzialności za produkt żywnościowy musi zostać poprzedzona prezentacją krajowych środków prawnych, regulujących odpowiedzialność za produkt w ogólności.

Wymaga podkreślenia, że na kształt krajowych regulacji prawnych w zakresie odpowiedzialności za produkt wpływ wywarła - podobnie jak w większości krajów unijnych - konwencja haska z dnia 2 października 1973 r. o prawie właściwym dla odpowiedzialności za produkt. W doktrynie eksponuje się, że rola tej konwencji daleko wykroczyła poza uregulowanie kwestii kolizyjno-prawnych - wskazania prawa właściwego dla reżimu odpowiedzialności za produkt. Dla prawidłowego

Tak np. B. Gnela, Odpowiedzialność za szkodę wyrządzoną przez produkt niebezpieczny (tzw. odpowiedzialność za produkt), Kraków 2000, s. 13.

$9 \quad$ Ustawa z dnia 23 kwietnia 1964 r. - Kodeks Cywilny (Dz.U. Nr 16, poz. 93 ze zm.) - art. $449^{1}$ do art. $449^{11}$ szczegółowo regulują reżim odpowiedzialności za szkodę wyrządzoną przez produkt niebezpieczny. Usytuowanie tych przepisów w systematyce kodeksu cywilnego przesądza o deliktowym reżimie tej odpowiedzialności. Tak np. M. Korzycka-Iwanow, Prawo żywnościowe. Zarys prawa polskiego i wspólnotowego, Warszawa 2005, s. 160.

11 Jedn. tekst: Dz.U. z 2008 r. Nr 25, poz. 150. 
stosowania tej konwencji konieczne było uporządkowanie siatki pojęćc ${ }^{12}$. Z punktu widzenia prowadzonych rozważań istotne jest podkreślenie, że zgodnie z art. 3 konwencji odpowiedzialność za produkt ponoszą zarówno producenci finalni, jak i producenci części składowych. Odpowiedzialność ta rozciąga się także na producentów produktów przemysłowych i naturalnych, sprzedawców produktów oraz inne podmioty stanowiące „ogniwo" w procesie produkcji i sprzedaży ${ }^{13}$. Z kolei definicja produktu została zawarta w art. 2a konwencji. Definicją tą objęte są produkty naturalne i przemysłowe w stanie surowym lub przetworzonym, będące rzeczami ruchomymi lub nieruchomościami. W definicji tej mieszczą się także produkty rolne i żywnościowe. W zakresie produktów rolnych konwencja przewidywała możliwość ich wyłączenia.

Dopełnieniem rozwiązań kolizyjno-prawnych miała być konwencja strasburska z dnia 27 stycznia 1977 r. Chociaż konwencja ta nie weszła w życie z powodu braku ratyfikacji, to niewątpliwie jej rozwiązania wywarły znaczny wpływ na dalsze prace unifikacyjne, których rezultatem była Dyrektywa Rady nr 85/374 z dnia 25 lipca 1985 r. w sprawie zbliżenia (ujednolicenia) przepisów ustawowych, wykonawczych i administracyjnych państw członkowskich dotyczących odpowiedzialności za produkty wadliwe ${ }^{14}$.

Początkowo z zakresu przedmiotowego tej dyrektywy wyłączone zostały „naturalne produkty rolne i łowieckie". Dopiero zmiana dyrektywy uchwalona w dniu 10 maja 1999 r. ${ }^{15}$ rozszerzyła zakres pojęcia produktu również na „,naturalne produkty rolne i łowieckie".

W polskim prawie wewnętrznym wyrazem harmonizacji prawa w zakresie odpowiedzialności za produkt wadliwy (niebezpieczny) z wymogami prawa wspólnotowego była nowelizacja kodeksu cywilnego, dokonana ustawą nowelizującą z dnia 2 marca 2000 r., w wyniku której - od dnia 1 lipca 2000 r. - wprowadzony został odrębny reżim odpowiedzialności deliktowej za szkodę wyrządzoną przez produkt niebezpieczny ${ }^{16}$. W doktrynie podkreśla się, że optymalnym rozwiązaniem byłoby jednak uchwalenie ustawy szczególnej o odpowiedzialności za produkt ${ }^{17}$.

Por. E. Kremer, Odpowiedzialność za zobowiązania związane z prowadzeniem gospodarstwa rolnego, Kraków 2004, s. 119.

13 W pewnych sytuacjach może to być również dostawca komponentów niezbędnych do produkcji. Kwestia ta będzie odgrywała szczególna rolę w przypadku produktów żywnościowych.

14 Dyrektywa ta została ogłoszona w Dzienniku Urzędowym Wspólnoty nr L 210 z dnia 7 sierpnia 1985 r., s. 29.

15 Por. dyrektywę zmieniającą nr 34/99 z 10 maja 1999 r. (Dziennik Urzędowy Wspólnoty L 141 z dnia z 4 czerwca 1999 r., s. 20). Na podstawie dyrektywy zmieniającej Państwa Członkowskie zobowiązane zostały do dostosowania rozwiązań wewnętrznych w terminie do dnia 4 grudnia $2000 \mathrm{r}$.

16 Por. Tytuł $\mathrm{VI}^{1}$ dodany do kodeksu cywilnego przez art. 18 pkt 6 ustawy z dnia 2 marca 2000 r. o ochronie niektórych praw konsumentów oraz o odpowiedzialności za szkodę wyrządzoną przez produkt niebezpieczny (Dz.U. $\mathrm{Nr} 22$, poz. 271).

17 Tak m.in. B. Gnela, Odpowiedzialność za szkodę..., s. 280. Pojawiły się również głosy odmienne, eksponujące zalety umieszczenia tej regulacji wprost w kodeksie cywilnym, np. E. Bagińska, Nowe unormowania odpowiedzialności cywilnej za produkt, „Przegląd Sądowy” 2000, nr 9, s. 40 i nast. 
Wymaga zasygnalizowania, że konieczność uregulowania w polskim prawie wewnętrznym kwestii odpowiedzialności za produkt wynikała nie tylko z treści art. 68 i 69 Układu Europejskiego, ustanawiającego stowarzyszenie między Polską a Wspólnotami Europejskimi i ich państwami członkowskimi, podpisanego w dniu 16 grudnia 1991 r. w Brukseli ${ }^{18}$, ale także z art. 76 Konstytucji Rzeczypospolitej Polskiej z dnia 2 kwietnia 1997 r. ${ }^{19}$ Przepis Konstytucji nakłada na władze publiczne obowiązek ochrony konsumenta między innymi przed działaniami zagrażającymi jego bezpieczeństwu.

Wprowadzenie do polskiego kodeksu cywilnego odrębnej regulacji dotyczącej odpowiedzialności za produkt niebezpieczny budzi sporo wątpliwości. Wątpliwości te dotyczą także próby zastosowania tej regulacji prawnej w odniesieniu do produktów żywnościowych, o czym będzie mowa w dalszej części artykułu.

$\mathrm{Na}$ wstępie należy wskazać, że reżim odpowiedzialności za produkt niebezpieczny - mimo niezbyt fortunnego usytuowania przepisów w systematyce polskiego kodeksu cywilnego - jest reżimem odpowiedzialności deliktowej (z czynu niedozwolonego). Teza ta znajduje potwierdzenie m.in. w orzeczeniu polskiego Sądu Najwyższego z dnia z dnia 12 lipca 2002 r. ${ }^{20}$

Wymaga dodania, że podobnie jak w Dyrektywie, również w polskim kodeksie cywilnym jest to odpowiedzialność oparta na zasadzie ryzyka, od której można się uwolnić poprzez wykazanie jednej z przesłanek egzoneracyjnych.

Przepisy szczególne regulujące reżim odpowiedzialności za produkt niebezpieczny nie wyłączają również możliwości zastosowania innych przepisów korzystniejszych w danej sytuacji dla poszkodowanego. Mogą to być więc zarówno przepisy regulujące odpowiedzialność za szkody wynikłe z niewykonania lub nienależytego wykonania zobowiązania (odpowiedzialność kontraktowa), ale także przepisy o rękojmi za wady i gwarancji jakości. Takie stanowisko jest aprobowane w doktrynie. ${ }^{21}$

Definicja produktu niebezpiecznego została zawarta w art. $449^{1} \S 2$ polskiego kodeksu cywilnego. Zgodnie z tym przepisem, przez produkt niebezpieczny rozumie się rzecz ruchomą, choćby została ona połączona $\mathrm{z}$ inną rzeczą. Za produkt uważa się także zwierzęta i energię elektryczną.

Definicja ta w generalnych założeniach odpowiada wymogom definicji zawartej w art. 2 Dyrektywy 85/374 w jej wersji znowelizowanej Dyrektywą 99/34. Ujmując zagadnienie najogólniej można przyjąć, że zarówno w przepisach dyrektywy,

Tekst Układu Europejskiego został opublikowany w formie załącznika w Dz.U. z 1994 r. Nr 11, poz. 38.

Dz.U. Nr 78, poz. 483.

Sygn. V CKN 1112/00, publ. LEX 57216.

Por. E. Łętowska, Prawo umów konsumenckich, Warszawa 1999, s. 111. 
jak i w przepisach krajowych, z wadą produktu mamy do czynienia wówczas, gdy produkt nie zapewnia bezpieczeństwa, jakiego można od niego w sposób uzasadniony oczekiwać. Oczekiwanie to odnosimy do tzw. przeciętnego konsumenta i relatywizujemy rodzajem rzeczy ${ }^{22}$.

W polskiej doktrynie prawniczej zwraca się jednak uwagę, iż brak jest w kodeksie cywilnym definicji ,niebezpiecznej wady produktu”, którym to pojęciem posługuje się art. 6 ust. 1 Dyrektywy 85/374 ${ }^{23}$. Nowe przepisy kodeksowe nie posługują się kategorią odpowiedzialności za wadę produktu w postaci „braku bezpieczeństwa”, a mowa w nich jest o odpowiedzialności za ,produkt niebezpieczny”. Według bowiem art. $449^{1} \S 3$ kodeksu cywilnego, niebezpieczny jest produkt niezapewniający bezpieczeństwa, jakiego można oczekiwać uwzględniając „normalne" użycie produktu. Literalna wykładnia tego przepisu prowadzi do konstatacji, że owo kryterium „normalności” jest zbyt wąskie w stosunku do rozwiązania proponowanego w Dyrektywie. Przepisy dyrektywy pomijają bowiem tylko te przypadki nieprawidłowego użycia produktu, które w danych okolicznościach należy uznać za nierozsądne. Natomiast polskie przepisy przewidują, że z odpowiedzialnością producenta mamy do czynienia tylko wtedy, gdy szkoda powstała w toku „,normalnego” użycia produktu. Jak się wydaje, harmonizacja przepisów krajowych z wymaganiami dyrektywy może być osiągnięta w drodze wykładni „prowspólnotowej”. W polskiej doktrynie prawniczej proponuje się, aby pod pojęciem „normalnego” użycia produktu rozumieć jego przewidywalne użycie wynikające z przeznaczenia lub ze znanych w praktyce przypadków użycia danego produktu”. Przy czym - przy dołożeniu należytej staranności - producent powinien znać częste przypadki nieprawidłowego korzystania z jego produktów i przeciwdziałać temu zjawisku przez eliminację niebezpieczeństwa związanego z takim korzystaniem z produktu ${ }^{24}$.

3. Zaprezentowane wyżej rozwiązania prawne odnoszące się do odpowiedzialności za produkty niebezpieczne w ogólności, wywołują również daleko idące konsekwencje w stosunku do reżimu odpowiedzialności za „niebezpieczne” produkty żywnościowe. W polskim systemie prawnym trudności interpretacyjne pojawiają się w odniesieniu do niektórych aspektów cywilnoprawnej odpowiedzialności producenta za produkt żywnościowy. Niezbędne wydaje więc ich zarysowanie wraz z próbą wykładni uwzględniającej te regulacje wspólnotowe, które nakładają określone obowiązki na ustawodawcę krajowego.

W pierwszej kolejności należy podkreślić, że niezbędną przesłanką odpowiedzialności za produkt niebezpieczny, którym może być również produkt żywnościowy, jest jego wytworzenie w „zakresie działalności gospodarczej producenta”. 
Oczywiście, obok samego producenta, odpowiedzialność mogą ponosić w konkretnych sytuacjach jeszcze inne podmioty, takie jak m.in. wytwórca materiału, surowca lub części składowej, dostawca, osoba, która przez umieszczenie na produkcie swojej nazwy (znaku towarowego lub innego oznaczenia) podaje się za producenta, a także osoba, która produkt pochodzenia zagranicznego wprowadza do obrotu krajowego w zakresie swojej działalności gospodarczej (importer). Należy również zauważyć, że niektóre płody ziemi, jak owoce leśne i grzyby oraz ryby i dzikie zwierzęta nie mają swego ,producenta”, mimo to szkody przez nie wywołane podlegają analizowanej regulacji. Nie tracąc z pola widzenia owych innych podmiotów odpowiedzialnych, uwaga zostanie skoncentrowana na producencie.

Jak wcześniej zostało zasygnalizowane, omawiana regulacja prawna obejmuje swoim zakresem również naturalne produkty rolne i łowieckie.

Mając na względzie zarysowane na wstępie założenia niniejszego artykułu, a także jego ramy, w toku dalszych wywodów pomijam problematykę żywności genetycznie modyfikowanej.

Na wstępie należy zasygnalizować, że na gruncie prawa polskiego wątpliwości pojawiają się już na etapie kwalifikowania danego rodzaju działalności jako działalności gospodarczej.

Obowiązująca polska ustawa z dnia 2 lipca 2004 r. o swobodzie działalności gospodarczej ${ }^{25}$ - podobnie jak poprzednio obowiązujące regulacje prawne - nie zalicza do działalności gospodarczej działalności wytwórczej w rolnictwie. Literalna wykładnia art. 3 tej ustawy prowadziłaby zatem do wniosku, że podmiot prowadzący działalność wytwórczą w rolnictwie nie byłby kwalifikowany jako podmiot prowadzący działalność gospodarczą (przedsiębiorca). Taka wykładnia byłaby jednak nie do pogodzenia $\mathrm{z}$ wymogami harmonizacji polskiego prawa $\mathrm{w}$ analizowanym zakresie z prawem wspólnotowym. Wyłączałaby bowiem znaczną grupę producentów produktów rolnych i żywnościowych z reżimu odpowiedzialności deliktowej za produkt niebezpieczny.

Problem ten został dostrzeżony w doktrynie prawniczejej ${ }^{26}$. Podstawowa wątpliwość dotyczy już samego zakresu wyłączenia. Jeżeli bowiem przyjąć, że art. 3 ustawy o swobodzie działalności gospodarczej ma zastosowanie do każdej działalności wytwórczej w rolnictwie bez względu na jej zakres i skalę, to należałoby go odnosić zarówno do drobnych rolników, jak i rolników dysponującym tysiącami hektarów upraw czy tysiącami zwierząt hodowlanych. Jak się wydaje, konieczne jest w drodze wykładni celowościowej poszukiwanie innego rozwiązania. 
Jeżeli przyjąć, że działalność wytwórcza w rolnictwie ma charakter zawodowy, zarobkowy (nie jest wykonywana wyłącznie dla zaspokojenia własnych potrzeb), jest wykonywana w sposób zorganizowany i ciągły, to należy ją zakwalifikować jako działalność gospodarczą, bez względu na przyjęte w ustawie o swobodzie działalności gospodarczej kryterium formalne ${ }^{27}$. Opowiedzenie się za rozwiązaniem odmiennym pozostałoby w rażącej sprzeczności z wymogami Dyrektywy 85/374 w jej wersji znowelizowanej Dyrektywą 99/34. Skoro bowiem obejmuje ona swoim zakresem produkty rolne, a jednocześnie wprowadzony jest wymóg ich wytworzenia w ramach działalności gospodarczej producenta, to wyłączenie z jej zakresu działalności wytwórczej w rolnictwie spowodowałoby wyłączenie reżimu odpowiedzialności producenta w tej sferze. Byłoby to nie do pogodzenia z wymogiem ,prowspólnotowej" wykładni przepisów krajowych.

W konkluzji tej części artykułu należy postulować zmianę przepisów krajowych w takim kierunku, aby nie pozostawiały wątpliwości w kwestii kwalifikowania działalności wytwórczej w rolnictwie jako działalności gospodarczej. Nie przesądzam w tym zakresie o rozwiązaniach szczegółowych, które mogłyby uwzględniać specyfikę działalności rolniczej.

4. Kolejne problemy powstają w kwalifikowaniu produktu żywnościowego w kategoriach produktu niebezpiecznego. W doktrynie prawniczej eksponuje się, iż jako produkt żywnościowy kwalifikowana jest ,żywność wprowadzana na rynek”. W konsekwencji każdy produkt żywnościowy będzie mógł również zostać zakwalifikowany jako produkt w rozumieniu przepisów regulujących odpowiedzialność za produkt niebezpieczny ${ }^{28}$.

W takim ujęciu rodzi się jednak kwestia określenia kryteriów kwalifikowania produktu żywnościowego (żywności, środka spożywczego) w kategoriach produktu niebezpiecznego.

Jak się wydaje, punktem odniesienia dla ustawodawcy krajowego powinien być art. 14 cytowanego na wstępie rozporządzenia (WE) nr 178/2002 Parlamentu Europejskiego i Rady z dnia 28 stycznia 2002 r. ustanawiającego ogólne zasady i wymagania prawa żywnościowego ${ }^{29}$. Wprawdzie przepisy tego rozporządzenie nie dotyczą wprost problematyki odpowiedzialności cywilnoprawnej producenta, niemniej jednak użyta w nich ,siatka pojęć” może być przydatna w również w analizowanej materii.

27 Tak R. Budzinowski, Status prawny rolnika jako przedsiębiorcy (zagadnienia wybrane), „Ruch Prawniczy, Ekonomiczny i Socjologiczny” 2002, nr 3, s. 111 i nast. Podobnie A. Kidyba, Galimatias z przedsiębiorcami, „Rzeczpospolita" z 18 czerwca 2003 r., s. C3. 
$\mathrm{W}$ art. 14 rozporządzenia zawarte zostały podstawowe kryteria kwalifikowania żywności (produktu żywnościowego, środka spożywczego) jako niebezpiecznego. Należy również podkreślić, że w świetle tej regulacji prawnej istnieje bezwzględny zakaz wprowadzania na rynek niebezpiecznych produktów żywnościowych. Wymaga dodania, iż nawet zgodność produktu żywnościowego ze szczegółowymi przepisami mającymi do niego zastosowanie nie powinna powstrzymać właściwych władz przed podjęciem stosownych środków w celu nałożenia ograniczeń dotyczących wprowadzenia jej na rynek lub zażądania wycofania go z rynku, jeżeli istnieją podstawy, aby podejrzewać, iż pomimo takiej zgodności ten środek spożywczy jest niebezpieczny.

Według art. 14 rozporządzenia, produkt żywnościowy (żywność, środek spożywczy) uznawany jest za niebezpieczny, jeżeli jest szkodliwy dla zdrowia lub nie nadaje się do spożycia przez ludzi.

Nie wydaje się celowa analiza wszystkich przesłanek kwalifikowania na gruncie rozporządzenia produktu żywnościowego jako produktu niebezpiecznego. W interesującej nas materii odpowiedzialności cywilnoprawnej producenta za niebezpieczny produkt żywnościowy, konieczne jest zestawienie przyjętych w rozporządzeniu kryteriów z rozwiązaniami przyjętymi w kodeksie cywilnym.

Jak wcześniej zostało wskazane, sposób kwalifikowania w krajowym systemie prawnym produktu niebezpiecznego z uwzględnieniem jego „normalnego użycia” jest zbyt wąski w stosunku do rozwiązań wspólnotowych. Kwestia ta nabiera szczególnego znaczenia w odniesieniu do produktów żywnościowych.

Według rozporządzenia, rozstrzygając, czy produkt żywnościowy jest niebezpieczny, uwzględnia się wprawdzie „,zwykłe (normalne) warunki” korzystania z żywności przez konsumenta. Bierze się jednak również pod uwagę wykorzystanie żywności na każdym etapie produkcji, przetwarzania i dystrybucji. Zatem w tym ostatnim zakresie powstaje kwestia przewidywania przez producenta - przy dołożeniu należytej staranności - częstych przypadków nieprawidłowego korzystania z produktu i eliminowania niebezpieczeństwa związanego z takim korzystaniem. Dla oceny należytej staranności producenta istotny będzie również zakres informacji przeznaczonych dla konsumenta $z$ uwzględnieniem informacji na etykiecie oraz innych informacji zwykle dostępnych dla konsumenta, a dotyczących unikania konkretnych negatywnych skutków dla zdrowia związanych z daną żywnością lub rodzajem żywności (takie „,pomocnicze” kryterium oceny należytej staranności można wyprowadzić na podstawie art. 14 ust. 3 b rozporządzenia) $)^{30}$. tylko prawdopodobne natychmiastowe i/lub krótkotrwałe i/lub długofalowe skutki tej żywności dla zdrowia spożywającej jej osoby, ale także dla następnych pokoleń, ewentualne skutki skumulowania toksyczności czy też szczególną wrażliwość zdrowotną określonej kategorii konsumentów, jeżeli środek spożywczy jest przeznaczony dla tej kategorii konsumentów. 
5. Jak wyżej wskazano, odpowiedzialność producenta (w tym także producenta żywności) za produkt niebezpieczny nie ma charakteru absolutnego, ale jest odpowiedzialnością opartą na zasadzie ryzyka. W konsekwencji producent może zwolnić się z odpowiedzialności, wykazując jedną bądź kilka przesłanek egzoneracyjnych. W Dyrektywie 85/374 przesłanki te zostały zawarte w art. 7 . Wyrazem ich implementacji do polskiego kodeksu cywilnego jest art. $449^{3}$. Analiza tych przesłanek wydaje się istotna z punktu widzenia określenia granic odpowiedzialności producenta za produkt żywnościowy.

Zarówno w Dyrektywie, jak i w polskim kodeksie cywilnym przesłanką zwalniającą z odpowiedzialności jest wykazanie przez producenta, iż nie wprowadził produktu niebezpiecznego do obrotu albo też jego wprowadzenie do obrotu nastąpiło poza zakresem działalności gospodarczej producenta. Przy czym art. $449^{4}$ kodeksu cywilnego wprowadza domniemanie, że produkt niebezpieczny, który spowodował szkodę, został wytworzony i wprowadzony do obrotu w zakresie działalności gospodarczej producenta.

Na tle tak sformułowanych przepisów pojawia się problem zakresu odpowiedzialności w przypadku wytworzenia i wprowadzenia do obrotu produktu żywnościowego. Polska doktryna opowiada się za szerokim ujmowaniem zakresu pojęcia wytworzenia produktu żywnościowego i jego wprowadzenia do obrotu w ramach własnej działalności gospodarczej. W szczególności przez pojęcie własnej działalności gospodarczej rozumie się również działalność o charakterze rolniczym (wspomnianą wyżej działalność wytwórczą w rolnictwie) w ramach tzw. produkcji pierwotnej ${ }^{31}$. Pogląd ten należy w pełni zaaprobować. Nie ulega bowiem wątpliwości, że znaczna część produktów wytworzona właśnie w procesie tzw. produkcji pierwotnej i z tego źródła jest wprowadzona bezpośrednio do obrotu.

Zarówno na gruncie Dyrektywy, jak i w polskim kodeksie cywilnym, przesłanką zwalniającą od odpowiedzialności jest ujawnienie się niebezpiecznych właściwości produktu po wprowadzeniu go do obrotu, chyba że wynikały one z przyczyn tkwiącej uprzednio w produkcie. Regulacja ta nie wywołuje szczególnych wątpliwości interpretacyjnych. Trudności mogą się pojawić jedynie w procesie dowodzenia tej przesłanki. Zaznaczyć przy tym należy, iż ciężar dowodu będzie spoczywał w tym zakresie na producencie.

Kontrowersje wzbudza natomiast przesłanka egzoneracyjna, która pozwala na zwolnienie się producenta z odpowiedzialności w sytuacji, gdy nie można było przewidzieć niebezpiecznych właściwości produktu (w tym również produktu żywnościowego), uwzględniając stan nauki i techniki w chwili wprowadzenia go do obrotu. Rozwiązanie to jest krytykowane w doktrynie. W szczególności zwraca się uwagę, 
że uznawanie stanu nauki i techniki za przesłankę zwalniającą od odpowiedzialności za produkt nadmiernie osłabia ochronę poszkodowanego i kłóci się z tendencjami w zakresie ochrony konsumenta i bezpieczeństwa człowieka w ogólności. Ryzyko rozwoju (postępu) powinno obciążać producentów, którzy - w przeciwieństwie do konsumentów - mają szeroki wachlarz możliwości ubezpieczenia swojej działalności także od tego ryzyka ${ }^{32}$. Dodać można, że przerzucanie ryzyka rozwoju na konsumenta żywności (produktów żywnościowych) rodzi niebezpieczeństwo nie tylko w odniesieniu do GMO, ale także zwykłych produktów żywnościowych, których oddziaływania na organizm człowieka, w szczególności w dłuższej perspektywie, nie jest łatwo przewidywalne.

Wątpliwości wzbudza również zwolnienie producenta od odpowiedzialności na tej podstawie, że niebezpieczne właściwości produktu wynikały z zastosowania przepisu prawa. W tym zakresie chodzi o bezwzględnie obowiązujące przepisy prawa. Gdyby zatem obowiązującym aktem władzy państwowej nałożono na producenta określone obowiązki (np. w zakresie stosowania określonego procesu technologicznego), których realizacja doprowadziłaby do wadliwości produktu, zastosowanie przepisu byłoby przesłanką zwalniającą z odpowiedzialności. Z taką samą sytuacją będziemy mieli do czynienia na gruncie krajowym, jeżeli ustawodawca prowadzi normę techniczną do obowiązkowego stosowania ${ }^{33}$.

W doktrynie postuluje się, dla podwyższenia poziomu ochrony poszkodowanego, uchwalenie przepisów szczególnych o odpowiedzialności za szkody wywołane wadami w rozwoju oraz zgodnością z przepisami prawa, co powinno być połączone z obowiązkowym ubezpieczeniem przedsiębiorców do niektórych przypadków odpowiedzialności za produkt ${ }^{34}$.

\section{Konkluzje}

Zbyt krótki okres obowiązywania omawianych regulacji prawnych nie pozwala jeszcze na wyprowadzanie wniosków o charakterze generalnym.

Można jednak stwierdzić, że uregulowanie przez polskiego ustawodawcę odpowiedzialności za szkodę wyrządzoną przez produkt niebezpieczny (obejmujący zakresem pojęcia także produkty rolne i żywnościowe) jest spełnieniem wymogów prawa wspólnotowego. Co więcej, taki obowiązek ciążył na polskim ustawodawcy dopiero w ciągu trzech lat od przystąpienia Polski do Unii Europejskiej. Harmonizacja w omawianej dokonana została znacznie wcześniej - jeszcze przed wejściem Polski w struktury unijne. Jak się wydaje, stało się to z pożytkiem dla prawidłowej wykładni przepisów. 
W szerszym ujęciu, należy zauważyć, że reżim odpowiedzialności producenta za produkt żywnościowy został w miarę dokładnie skorelowany z całością zagadnień obejmujących bezpieczeństwo żywności. Wskazywane w toku prowadzonych rozważań mankamenty polskiego ustawodawstwa w tym zakresie w żadnym mierze nie mogą prowadzić do konkluzji, że cel harmonizacyjny nie został osiągnięty. Nie eliminuje to, rzecz jasna, konieczności dokonania postulowanych w toku rozważań zmian ustawodawczych.

W doktrynie prawniczej podkreśla się, że - z teoretycznego, dogmatycznego punktu widzenia - szczególnie nowy reżim odpowiedzialności za produkt niebezpieczny (w tym produkt rolny i żywnościowy) powinien stanowić dla poszkodowanych ułatwienie $w$ dochodzeniu roszczeń. O jego faktycznej skuteczności zadecyduje jednak praktyka ${ }^{35}$. Przede wszystkim w odniesieniu do sądów aktualny pozostaje zgłaszany $\mathrm{w}$ toku prowadzonych rozważań postulat prowspólnotowej wykładni przepisów i szerokiego korzystania w tym zakresie z dorobku doktryny i orzecznictwa unijnego, jak i poszczególnych państw Unii Europejskiej. 


\section{The liability for food product in the Polish legal system}

\section{Summary}

A precise definition of the principles and basis of the food product liability is included in an unusually broad scope of the food safety subject matter. Having regard to the whole set of Polish legal tools for food safety, the reader's attention was focused on civil-legal aspects of producer's liability for harm caused by food product's defect. The idea of the article, however, was not exclusively a detailed legal analysis of Polish legal solutions within this subject matter, but mainly an attempt to interpret these regulations which arouse most doubts in the Polish practice, especially from the point of view of their compliance with the Community regulations. The legal harmonization is undoubtedly of crucial importance in this sphere.

It needs emphasizing that the majority of essential legal issues related to the subject matter of food safety as formulated in the Community law has been reflected in the Polish legislation. Currently this subject matter is regulated on the Polish legal area by the act of 25August 2006 about the safety of food and feeding.

It can be claimed, however, that the regulation of the liability for harm caused by unsafe product (comprising also the notions of agricultural produce and food product) in the Polish legislation complies with the requirements of the Community law. The shortcomings pointed out in the course of considerations absolutely do not allow to conclude that the objective of harmonization has not been achieved. This does not eliminate, however, the necessity to bring about changes postulated in the course of legislative considerations.

In the Polish doctrine it is stressed that from theoretical, dogmatic point of view especially the new regime of liability for unsafe product (comprising agricultural produce and food product) should constitute a facilitation for claims to be made by the harmed person. It will, however, be the judicial practice which will decide about its legal efficiency. 